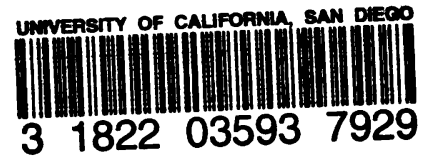

\title{
CHINA-ASEAN RELATIONS: \\ PERSPECTIVES, PROSPECTS AND IMPLICATIONS FOR U.S. INTERESTS
}

Jing-dong Yuan

October 2006

This publication is a work of the U.S. Government as defined in Title 17, United States Code, Section 101. As such, it is in the public domain, and under the provisions of Title 17, United States Code, Section 105, it may not be copyrighted. 